\title{
Turkish Series: Products of Popular Culture and Tools for Inclusive Globalization
}

\section{Cansu Arısoy, University of Salford, Turkey}

\begin{abstract}
The thoughts and experiences of people consist of meanings and while sharing these meanings people share their cultures. Globalization is the concept that increases the mobility of these meanings and cultures. Understanding culture, globalization, and international relations is critical for the future of not only governments, but also for people and businesses. Going beyond the classical definitions of globalization and creating a bond between this concept and popular culture is one of the aims of this paper. The main target is to analyze the rise of Turkish series by taking this relationship as the base. There are various interpretations for globalization and culture because these are not narrow, strait jacket concepts. Therefore this paper aims to present a fresh and understandable approach to the relationship between globalization and popular culture by using Turkish soap operas as the case study. According to this paper, besides the dominant cultures, other cultures too, contribute to the popular culture industry. In this context the impact of Turkish series in diplomacy is discussed. Today one of the biggest wars of humanity is making globalization a constructive power for the people all around the world. Therefore this paper is important because it underlines the value of the inclusive character of globalization. Thus in this work it is underlined that in today's world which leisure became the basis for the modern lives; popular culture must be used to bring an inclusive character to globalization for embracing all the humans around the world.
\end{abstract}

Keywords: Globalization, Popular Culture, Diplomacy, Television Series, Communication, Consumerism 


\section{Introduction}

People make sense of the world and themselves by sharing their experiences and the meanings that they get from their lives. Watching a soap opera and talking about what the characters are doing; arguing about the consequences of the recent World Cup, remembering together once well-known song; debating the claims of politicians, discuss the general elections and big businesses, protesting against the injustices and economic inequalities of globalization, etc. While doing these we all share our thoughts and experiences. These consist of meanings and while sharing these meanings people actually share their cultures. Globalization is the concept that increases the mobility of these meanings and cultures.

International relations have used globalization to reach its goal: understanding cultures. International relations focus on how countries, people and organizations interact and globalization makes a profound effect on international relations. Understanding culture, globalization, and international relations is critical for the future of not only governments, but also for people and businesses.Globalization leads to blend of cultures. This creates a struggle against diversity:"globalization offers the possibility of cultural mixing on a scale never before known" (Franz and Smulyan, 2012, p.435). Globalization can become a tool to combine different cultures and constitute a new kind of cultural hybridity: "all cultures are involved in one another; none is single and pure, all are hybrid, heterogeneous, extraordinarily differentiated and unmonolithic" (Said, 1993, p.xxv).Going beyond the classical definitions of globalization and creating a bond between this concept and popular culture is one of the aims of this paper. The main target is to analyze the rise of Turkish series by taking this relationship as the base. Furthermore there are various interpretations for globalization and culture because these are not narrow, straitjacket concepts. Therefore this paper aims to present a fresh and understandable approach to the relationship between globalization and popular culture by using Turkish soap operas as the case study. In this sense this paper overlooks the various definitions of globalization,meaning of culture and its relationship with globalization. After that, this paper analyzes the concept of cultural communication as a tool of globalization andthen popular culture is examined.Lastly the impact of Turkish series in diplomacy is discussed.In conclusion it is underlined that in today's world which leisure became the basis for the modern life styles; popular cultures must be used to bring globalization an inclusive character for embracing all the humans all around the world. Understanding that globalization has many different conceptualizations is 
important with regard to this work. Therefore in the next section a brief analysis of the concept of globalization is given.

\section{Primary Perspectives on Globalization}

The concept of globalization has no definition that has been agreed upon. There is no consensus on globalization whether it is perceived as "a historical epoch, a process, a theory, or as a new paradigm" (Reich, 1998, p.3). Many scholars share this view that: globalization is not a monopolar concept; on the contrary it is an interconnection of economy, culture and politics (Bauman, 1998; Hirst and Thompson, 1999; Holton, 1998; Wright 2000). Therefore the sense of globalization has been left unclear. In this respect it might be easier to understand globalization if one discerns what it is not rather than what is it:

Globalization is not the same as globalism, which points to aspirations for an end state of affairs wherein values are shared by or pertinent to the entire world's five billion people, their environment, their roles as citizens, consumers or producers with an interest in collective action designed to solve common problems. Nor is it universalism-values which embrace all humanity, hypothetically or actually (Rosenau, 1996, p.3-4).

It is a fact that there is a strong disaccord on the definitions of globalization among researchers. However there are some theoretical perspectives defined to have a deeper understanding of globalization which possibly most of the scholars would achieve a consensus.Mostly globalization is seen as undermining the importance and distinctiveness of “indigenous cultural worlds" (Lizardo, 07/8, p.3). According to this opinion, these cultural worlds are considered to be eradicated by the "homogenous sterility of a U.S. dominatedglobal popular culture industry" (ibid). However this theoretical approach might be considered as oversimplifying because as this paper argues other cultures too started to contribute to the global popular culture industry.

All these proposals which are introduced to have a more detailed understanding of globalization meet on a common ground: globalization presents good opportunities as well as it has formidable disadvantages.Globalization changes the world that we live in. In this era the lives of people are unavoidably affected by the lives of others living beyond the borders. 
Unfortunately the opportunities that are presented by globalization are shared in uneven ways by humanity. Thus in our world people still could not have decided yet whether globalization is a sinister juggernaut or precursor of a better future.

\section{Globalization: A Sinister Juggernaut or Precursor of a Better Future}

The negative aspects of globalization are underlined by some people, groups and governments.Today for more and more people, globalization became the symbol for fragility of the disadvantaged groups. Thus, these powers might cause swift economic crisis, political and social conflicts. Regardingthis perspective, globalization underlines the unevenness of the world:

It is fair to say that the impact of globalization in the cultural sphere has, most generally, been viewed in a pessimistic light. Typically, it has been associated with the destruction of cultural identities, victims of the accelerating encroachment of a homogenized, westernized, consumer culture. This view, the constituency for which extends from (some) academics to anti-globalization activists, tends to interpret globalization as a seamless extension of - indeed, as a euphemism for - western cultural imperialism (Tomlinson, 2003, p.269).

Today one of the biggest wars of humanity is making globalization a constructive power for the people all around the world. This kind of power is called by Kofi Annan, the former General Secretariat of the United Nations, as "inclusive globalization" (Annan, 2000, p.6). According to this opinion, the big powers of the market economy should be the motivator of inclusive globalization. However this power of the market is not sufficient alone to bring globalization inclusiveness. An equally distributed future needs stronger endeavours. As a matter of fact the more the countries are advantaged in social and economic ways; the more they harmonize with the "global cultural flows and the consumption of non-local culture" (Lizardo, 07/8, p.36).

Adverse effects of globalization are so strong that "the benefits and opportunities of globalization remain highlyconcentrated among a relatively small number of countries and are spread unevenlywithin them" (Annan, 2000, p.11).Therefore the essence of globalization is not just about creating bigger markets. Economic aspects cannot be diversified from politics and social life. Common dynamics and values that people believe must constitute the 
base for globalization for to progress in a positive way and to become a concept that embraces whole world. This is very crucial because unlike the developed and industrialized countries; the developing countries cannot benefit from the advantages of global economy. Therefore these societies feel defenceless and unsafe.Today even in the most developed and industrialized countries people are afraid of losing their jobs and their voices in the powerful impact of globalization. Therefore the duty of trans-governmental organizations is"to ensure that globalization provides benefits, not just for some, but for all; that peace and security hold, not only for a few, but for the many; that opportunities exist, not merely for the privileged, but for every human being everywhere" (Annan, 2000, p.13).

Whether it is viewed as asinister juggernaut that walks all over everyone that appears on its way or whether it is perceived as a hopeful promise of a bright future; globalization is a phenomenon that is here to stay. It will continue to be a material of an immense argument. These arguments are appeared to be continued for a very long time but in this course people can adapt to globalization. Also since one of the objectives of this paper is to enlighten the relationship between globalization and popular culture; in this sense overlooking the essence of popular culture is necessary.

\section{Popular Culture: Power Spreading Among the Boundaries}

Culture is defined as all sorts of learned and internalized human behaviour manners. In some cases a culture might be suppressed by other cultures which are more popular than previous one. Popular culture consists of arts, food and beverage, etiquettes and even ethics. These features of the popular culture penetrate to other cultures, therefore local ones get weaker. This transmission is done by globalization. As a result of this process, long time customs and traditions are brought into disrepute instead these new habits are encouraged and implemented. In this sense weaker indigenous cultures are mixed up in this affair and sometimes get assimilated.

Globalization helps powerful countries and their cultures to affect the other societies; on the other hand weaker countries cannot resist this power and cannot enter into a global rivalry. Therefore when it comes to dissemination of culture; globalization becomes the sword of Damocles that is over the head of disadvantaged societies and their cultures. Globalization not only affects people but also states and governments are under the impact of globalization. 
With regard to this fact, politicians and diplomats must strengthen and promote their countries' customs and traditions. They must use the power of globalization to provide equal access for all of their community to the benefits of our era from communication facilities to food, arts, etc. If politicians and diplomats work for the sake of their cultures; this would make their society a more powerful global entity. In this context, in his acceptance speech upon receiving 1999 Lannan Prize for Cultural Freedom, Eduardo Galeano told the audience that:

In the midst of this era of mandatory globalization, which is like an immense factory pumping out cultural clones or clowns for the market circus, [the] colors and voices keep alive powerful evidence that the best of the world lies in the quantity of worlds the world contains (Horn, 2003, p.5).

Globalization brings countless changes to the cultural experiences of the people. These changes can be negative or positive. One thing that is clear is that there is nowhere to escape from the cultural transitions that globalization brings. But as a matter of fact people can adapt to change. In this process of adaptation to new cultures, communication plays a very important role. In this framework the relationship between communication and globalization should be discussed.

\section{Cultural Communication as a Tool of Globalization}

Social change and the transformation of the dynamics of the world drastically accelerated and this has social, economic, political, ideological and cultural results. These results are interconnected and multidimensional like globalization itself. Also these social, economic, political and cultural transformations created strong cohesiveness among people from different countriesand this lead to a communications revolution. The communications revolution was created by the spread of the Internet. As a result of this, the Internet and globalization started to support each other. In this sense the concept of cultural imperialism started to gain more and more importance and this resulted in international communication which is one of the tools of globalization.

Even though not every nation on earth has equal amount of opportunity to access the Internet; the dissemination of the network is so fast and it becomes the essential tool for communication. The hope is that both of these phenomena nurture each other and abolish 
ordeal of the world. However, neither transnational organizations nor the political institutions could determine how to answer this need. It is a fact that commercial culture is the dominant culture of our day. However it is not equally accessible to all: $86 \%$ of the world's goods go to the top $20 \%$ of the world population, the bottom fifth get $1 \%$ (Horn, 2003, p.6). This polarization and concentration of wealth is increasing. Commercial culture of post modern times is "culture of leisure and this despite the fact that more and more people seem to work longer and longer hours not only in the underdeveloped and emerging countries, but astonishingly in the countries with the most advanced and automated industries" (Horn, 2003, p.7).

Leisure has become the basis of our contemporary culture; instead of work. Where leisure has been taking over the priority in globalized cultures; the role of television shows gain importance. In this sense local television series started to be exported and broadcasted beyond that series' national borders. In this context, today, televisions have become one of the prominent tools for disseminating the local cultures and for making these cultures popular all around the world.

\section{Popular Culture: The World of Haves and Have Nots}

It is important to understand the financial, economic and technological aspects of popular culture (During, 1997, p.815). Popular culture or cultural globalization is constructed via show business (ibid). In terms of the relationship between globalization with popular culture, it is a fact that "globalization is increasing the relative economic importance of cultural production in (particularly Anglophone) First World countries and that cultural studies is an academic reflex of that process" (During, 1997, p.821). In political economic aspect "cultural industries become central to core economies just because low value-added labour is exported" (ibid).Popular cultures are used for the benefit of the majority and to create solutions to various issues. As a matter of fact the great number of humanity owns the rights of seeing, hearing, and remaining silent (Horn, 2003, p.4). Predominant group of people have their voices on mass media however these voices are "controlled and edited by others":

We derive satisfaction from participation in popular cultural forms; if we did not we would not participate in the often against the severe injunctions of educators and elite opinion, and they would not be popular. Nor should we overlook that the popular can 
be very profound and can contain durable values in a cheap, commercial and ephemeral packaging (ibid).

Globalization links cultures and international relations on a variety of levels; economically, politically, socially, etc:"The inclusion of culture into the globalizing economy leads to the creation of a global culture of commodified consumerism [...] Technology places images, words and music within the reach of many more than ever before in the history of humanity [...]" (Horn, 2003, p.5).With regard to the relationship between globalization and popular culture; it is necessary to mention the analysis that is made by Meyer and his fellow scholars (Robinson, 2007, p.138): globalization is examined as a cultural as well as an institutional phenomenon. This perspective is also called as "world polity" and "world society" which is different from global society (ibid). Robinson emphasizes that Meyer and his colleagues understand globalization "as the spread and ultimate universalization of sets of modern values, practices and institutions through isomorphic processes that operate on a global scale" (ibid).

In this context Turkish series are good examples of thisisomorphic process that operate on a global scale. The impressive rise of the Turkish soap operas in different geographies attracted the attention of television authorities and academia. Generally it is thought that the world television channels are dominated byAmerican series. Dallas, the Cosby Show, Knight Rider, Dynasty are the classical American television shows that reigned international television channels for many years. Today USA still holds the power in international television channels. However Americanization of the media is not the focus point of the scholarly debates; instead local television programs became the centre of popular culture studies (Schiller, 1976; Mattelart, 1982). Thus with the dissemination of these national shows, spread of local cultures, norms and values, ideologies and life-styles became possible. The success of Turkish series is a good example of these transnational cultural flows which proves currently not only Western cultures have the advantage of promoting their values to other countries. As a matter of fact the competitiveness of global markets is enlivened with the participation of non-Western cultures. 


\section{Considering Turkish Soap Power as a Tool for Diplomacy}

There is a considerable rise on the broadcasting of Turkish series which are being watched in over 20 countries in Balkans, in the Middle East and North Africa region and now in Latin America. In academia Turkish series are considered as the soft power of Turkish diplomacy (Cevik, 2014; Yoruk and Vatikiotis, 2013; Moore, 2013). With regard to this Prof.Narli's words are crucial to have a better understanding of this issue. According to Prof.Narli, there is a strong bond between Turkish soap operas and Turkey's rising diplomatic power:

As the circulation of soap operas in the international arena has increased, learning Turkish language and culture have become very important in the Arab and Balkan countries. This is what we call 'soft power' within the context of the culture industry (Series Boost Turkish 'Soft Power' in Region, 2011).

At this point taking a look at the series which are exported to foreign countries from Turkey would be noteworthy. The most popular exported soap operas are: I named her Feriha, Bitter life, Akasya Stop, Aliye, My Mother, Back Streets, ArkaSiradakiler, Rebellious, Asmalı Mansion, Love and Punishment, My Love, Berivan, Big Lies, My Dear Family, Day and Night, Genco, Noor, Under the Lime Trees, Grand Bazaar, The Valley of the Wolves. These series have a big popularity especially in the Middle East, North Africa, and Balkans. These exported television series are based on a striking mix of flamboyant production, the scenarios include full of love, rage, frame-up, and deaths that go on between beautiful Turkish actresses and handsome actors. These stories can be filmed in rich neighbourhoods or poor but beautiful areas of Istanbul or Eastern parts of Turkey.These are increasing Turkey's prestige by publicizing Turkish way of life. These countries include "Serbia, Croatia, Czech Republic, Romania, Poland, Hungary, Malaysia, Indonesia, Taiwan, Thailand, Singapore, Japan and Vietnam" (ibid).

Besides its cultural aspect financially exporting TV series brought Turkey10 million USD in 2008 and this has reached more than 150 million USD in 2013, which means 70 percent annual growth in the last five years (Exports of Turkish Made TV Series Soar, 2014).Important role of Turkish series in the cultural evolution of the people can be seen in the words of Izzet Pinto, the chief of Turkey's Global Agency, the distributor of Magnificent Century and 1001 Nights: "In the Balkans, newborns are being named after 1001 Nights 
characters $[\ldots]$ the secret to success is familiarity" (Series Boost Turkish 'Soft Power' in Region, 2011).People living in these geographies do not feel themselves like outsiders to what is taking place in these series. The bonds and cultures are mostly close:

These TV programs have taken the region by storm, with Turkish TV stars becoming pop idols among young and old, men and women. The impact of watching hours of these Turkish soap operas cannot be underestimated as they have the effect of creating attachment, understanding, and affection for Turkish identity, culture, and values among wide regional publics (Salem, 2011, p.6).

However in some parts of the Arab world Turkish series are not well-received. According to this view "the sight on TV screens of Muslims drinking alcohol or conducting adulterous relationships is becoming commonplace - and the shows have presented a new image of relations between man and woman" (The Rise of The Turkish Soap Power, 2013).Today if you are living in Chile and you have not heard about Las Mil Y Noches (1001 Nights) you might be discriminated from chit chats. Once hesitant Chilean television authorities; accepted the power of Turkish series. Right now four major channels in Chili plus Uruguay, Ecuador, Argentina, Mexico, Puerto Rico and Colombia are in the line to broadcast these shows (The Rise of the Turkish Series in Latin America, 2014).It is a question that whether the success of Turkish soap operas in Latin America would be as big as in the Middle East and Balkans thus Latin American and Turkish cultures are not that close. But it is a fact that these series are polishing Turkey's soft image in foreign countries, promoting its culture, traditions, landscape and Turkish life style to millions of viewers.

\section{Conclusion}

\section{The Greatest Challenge of Humanity: Creating Unity in Diversity}

Through the medium of Turkish soap operas, the Turkish culture, values and norms, and lifestyle found the chance to be spread beyond its national borders. Introducing Turkey as a contemporary model country to its counterparts via Turkish series turned out to be a successful attempt. By exporting Turkish way of life to foreign countries Turkey underlined its position as a regional actor in international arena. The rise of Turkish series is a successful example for cultural globalization and its social, political and economic consequences. Where leisure has become the basis of our postmodern times the role of global companies is very 
crucial. The verdicts of these companies have worldwide economic, social, and political results. Despite the fact that a non-negligible group of people has a strong belief that globalization creates a worse inequality; the opportunities of globalization should be expanding. All nations are the clients of the globalization's impacts therefore all of them must occupy a larger space in globalized culture. In today's world people face the greatest challenge of making globalization a positive phenomenon despite all of its negative effects on disadvantaged part of humanity. Globalization should be inclusive and should not leave millions of people behind in misery, poverty and deprivation. Free market is the power factor behind inclusive globalization but it is not alone in this challenge. At this point politicians and diplomats should fulfill their part for taking care of their own communities. Building an equally shared future should be done by respecting unity in diversity and embracing it rather than trying to suppress the indigenous and rare cultures.

Globalization does not carry the features of cement; it does not unite different cultures and glue them together. Globalization is universal but different countries experience different effects and apply different principles of globalization. For creating a common humanity, governments require to enhance consciousness of their binary status in this globalized world. One of the roles of these governments is the responsibility to their own community; the other one is that governments are in charge of all the people and the cultures in this world; the cultures that all the humanity would share. In this sense states and governments are very crucialin terms of defending diverse cultures against the crushing effect of globalization. According to Kofi Annan: "At the national level we must govern better, and at the international level we must learn to govern better together" (2000, p.6). He also underlines that effective states are essential for both tasks, and their capacity for both needs strengthening. Successfully managing globalization,therefore, requires — first and foremostthat states act in a manner consistent withtheir dual role (Annan, 2000, p.13). Therefore governing together and governing better is important to eliminate the negative effects of globalization and popular culture.

As a result to construct a common humanity people should learn to direct their collective operations, vulnerabilities, benefits and advantages. Today some of the wars that people have to fight against are personal beyond the control of the governments. With respect to the realities of globalization new transnational institutions should be built and operated according 
to the needs of newly emerging global culture. This new world needs new collaborations for a positive change and new civil partnerships for an inclusive globalization. Those, who take advantage from globalization the most and enjoy their culture to become the popular one; should help the others who are aggrieved and afflicted with globalization. For globalization to become inclusive and for popular culture not to digest indigenous cultures; all the people around world should benefit from the advantages of globalization. Therefore all women, children and men can share the opportunities of global culture, economy and technology. 


\section{References}

Annan, K. (2000) "We The Peoples: The Role of the United Nations in the $21^{\text {st }}$ Century". United Nations.

Bauman, Z. (1998) Globalization: The Human Consequences. Polity Press.

Cevik, S. B. (2014) “Turkish Soap Opera Diplomacy: A Western Projection by a Muslim Source” Exchange: The Journal of Public Diplomacy. Vol:5, no: 1, p: 78-103.

During, S. (1997) "Popular Culture on a Global Scale: A Challenge for Cultural Studies?" Critical Inquiry. Vol:23, no:4, p.808-833.Summer.

Exports of Turkish Made TV Series Soar (August 26, 2014). Retrieved June 29, 2015http://www.aa.com.tr/en/news/379318--exports-of-turkish-made-tv-series-soar

Franz, K. and Smulyan, S. (2012) Major Problems in American Popular Culture. Cengage Learning: Wadsworth, Boston.

Hirst, P. and Thompson, G. (1999) Globalization in Question: The International Economy and the Possibilities of Governance. Cambridge: Polity Press.

Holton, J. R. (1998) Globalization and the Nation-State. London and New York: Macmillan Press.

Horn, P. (2003) "Mass Culture, Popular Culture and Cultural Identity” Culture, Civilization and Human Society Encyclopedia of Life Support Systems (EOLSS), vol:1.

Latin Amerika' daTürkDizisiFuryası (The Rise of Turkish Series in Latin America) (September 6, 2014). BBC Turkish News.Retrieved June 29, 2015.http://www.bbc.co.uk/turkce/haberler/2014/09/140905_turk_dizisi_latam.shtml? ocid

Lizardo, O. "Globalization and culture: A sociological perspective", Center for the Critical Study of Global Power and PoliticsWorking Paper CSGP 07/8, Trent University, Peterborough, Ontario, Canada.

Mattelart, A. (1982) Multinational Corporations and the Control of Culture: The Ideological Apparatuses of Imperialism. (Michael Chanan, Trans.), Humanities Press Intl Inc.

Moore R. (2013) "Soap Opera Diplomacy: Turkish TV in Greece”. The International, 12 February.

Reich, S. (1998) "What is Globalization? Four Possible Answers" Working Paper \#261 The Helen Kellogg Institute for International Studies. December.

Robinson, W. (2007) “Theories of Globalization” In (ed.) George Ritzer Blackwell Companion to Globalization. Oxford: Blackwell. 
Rosenau, J. (1996) “The Dynamics of Globalisation: Towards an Operational Formulation," San Diego, Paper presented at the International Studies Association Convention, 18 April.

Said, W. E. (1993) Culture and Imperialism.New York: Knopf.

Salem, P. (2011) “Turkey's Image in the Arab World” TESEV Report, p.1-8.

Schiller, H. (1976) Communication and Cultural Domination. White Planes, New York: International Arts and Sciences Press.

Series Boost Turkish 'soft power' in Region (December 12, 2011).Hurriyet Daily News. Retrieved June 29, 2015

http://www.hurriyetdailynews.com/series-boost-turkish-soft-powerinregion.aspx?pageID=238\&nID=8919\&NewsCatID=381

The Rise of Turkish Soap Power (June 27, 2013). BBC News. Retrieved June 29, 2015http://www.bbc.com/news/magazine-22282563

Tomlinson, J. (2003) “Globalization and Cultural Identity" In (ed.) David Held and Anthony McGrew The Global Transformations Reader: An Introduction to the Globalization Debate. Second Edition.Blackwell Publishing.

Yoruk, Z. and Vatikiotis, P. (2013) Soft Power or Illusion of Hegemony: The Case of the Turkish Soap Opera "Colonialism” International Journal of Communication. Vol: 7, p: 2361-2385.

Wright, S. (2000) Community and Communication: The Role of Language in Nation State Building and European Integration.Clevedon: Multilingual Matters. 